(C) 2013

Кравченко С. О., кандидат ветеринарних наук

Полтавська державна аграрна академія

\title{
МЕТОД ПЕРФУЗЇ̈ СЕЧОВОГО МІХУРА В УЛЬТРАЗВУКОВІЙ ДІАГНОСТИЦІ УРОЛІТІАЗУ СВІЙСЬКИХ КОТІВ
}

\author{
Рецензент - кандидат ветеринарних наук П. І. Локес
}

\begin{abstract}
Даними дослідженнями встановлено, щзо застосування перфузії сечового міхура під час ультразвукового дослідження дозволяє підвищити інформативність діагностики сечокам'яної хвороби у свійських котів. Уведення у порожнину сечового міхура ізотонічного розчину натрію хлориду забезпечує його наповнення та покрашує візуалізацію уролітів $i$ сечового осаду. У складних випадках (адгезія каменів до слизової оболонки, порожній сечовий міхур) даний метод сприяє підвищенню ефективності діагностики захворювання.
\end{abstract}

Ключові слова: коти, уролітіаз, ультрасонографія, катетеризачія, перфузія.

Постановка проблеми. У зв'язку зі зміною умов утримання (в силу урбанізації) у дрібних домашніх тварин виникають раніше не властиві для них захворювання. Так, зокрема, у свійських котів розлади обміну речовин призводять до таких патологій як ожиріння, хронічна ниркова недостатність, уролітіаз та ін. [2, 4, 8]. На думку зарубіжних та вітчизняних вчених (Д. Сімпсон, 2003; П. І. Локес, 2003; Г. О. Ющенко, О. П. Тимошенко, 2005), саме сечокам'яна хвороба є однією 3 патологій сечової системи, що нерідко реєструється, й за відсутності своєчасної діагностики та адекватного лікування призводить до тяжких наслідків $[5,7,10]$.

Діагностування патології ускладнене, поскільки клінічними дослідженнями камені у сечовому міхурі не виявляються, - натомість присутні ознаки уроциститу. Це зумовлює необхідність застосування додаткових інструментальних методів (УЗД, рентгенографія) для правильного вибору методу лікування. Сукупність цих чинників призводить до щорічного зростання кількості летальних випадків від сечокам'яної хвороби, що спонукає до удосконалення існуючих методів діагностики, терапії та профілактики уролітіазу в котів, на що вказують С. A. Osborn, 2000, Е. Чандлер, $2002[9,11]$.

Саме тому вивчення шляхів підвищення інформативності ультрасонографічної діагностики уролітіазу свійських котів залишається наразі актуальним.
Аналіз основних досліджень і публікацій, у яких започатковано розв'язання проблеми. Ультрасонографічний метод діагностики - порівняно новий і у вітчизняній ветеринарній медицині дрібних тварин застосовується віднедавна. Більшість дослідників вказує на високу інформативність УЗД у діагностиці уролітіазу.

Проте УЗ-діагностика застосовується не в усіх клініках ветеринарної медицини (передусім унаслідок високої вартості обладнання) й підчас викликає труднощі, поскільки достовірність результатів залежить від технічних характеристик апарату і рівня підготовки оператора.

На це вказують відомі дослідники (Ф. Бар, 1999; П. І. Локес, 2007) [1, 6]. Зокрема, візуалізація уролітів у порожнині сечового міхура ускладнена у тих випадках, коли дрібні камені чи пісок щільно прилягають до стінки сечового міхура або прикріплені до слизової оболонки внаслідок запального процесу (так звані «впаяні» конкременти).

Водночас, у медицині людини (гуманній медицині) застосовуються прийоми, що дають змогу чіткіше візуалізувати пісок і дрібні камені завдяки переміщенню їх усередині міхура [3]. Одним із таких прийомів $\epsilon$ перфузія сечового міхура безпосередньо під час УЗ-дослідження. Її застосування у домашніх котів у вітчизняній літературі практично не висвітлене.

Тому пошук шляхів підвищення інформативності ультрасонографії за сечокам'яної хвороби у свійських котів $є$ вкрай необхідним.

Мета і завдання дослідження. Мета дослідження - вивчення інформативності перфузії сечового міхура свійських котів під час УЗ-дослідження у діагностиці сечокам'яної хвороби.

Основним завданням було виконання перфузії сечового міхура та дослідження рівня візуалізації уролітів.

Матеріали і методи. Дослідження проводили в умовах клініки ветеринарної медицини на базі кафедри терапії ПДАА у період із 2010 по 2012 рік. Котів, які надходили з ознаками розладів сечовипускання, досліджували клінічно та ульт- 
расонографічно, 3 використанням апарату SonoScape A6 vet (виробництво КНP) iз трансдуктором 2-6 мГц.

Матеріалом для досліджень стали клінічно здорові та хворі на сечокам'яну хворобу свійські коти.

У ході виконання роботи використано результати досліджень 30 клінічно здорових та 9 хворих на сечокам'яну хворобу свійських котів.

Усі тварини, які надходили до клініки, підлягали клінічному обстеженню. У випадку підозри на захворювання органів сечової системи застосовували ультрасонографічний метод дослідження, а в сумнівних випадках - перфузію сечового міхура.

Перфузію здійснювали наступним чином.

Катетеризували сечовий міхур за допомогою медичного підключичного катетера № 6. Уводили в порожнину сечового міхура стерильний розчин натрію хлориду 0,9 \% у кількості, достатній для його наповнення, й проводили ультрасонографію. У разі наявності каменів визначали їх розмір, кількість і приймали рішення стосовно доцільності оперативного лікування.

Результати досліджень. У ході досліджень було встановлено, що за ультрасонографії без перфузії уроліти візуалізувалися на дні сечового міхура у вигляді ехогенних нашарувань, що візуально зливались із стінкою міхура й могли бути сприйняті за артефакт «хвіст комети», зумовлений скупченням газів у кишечнику (рис. 1).

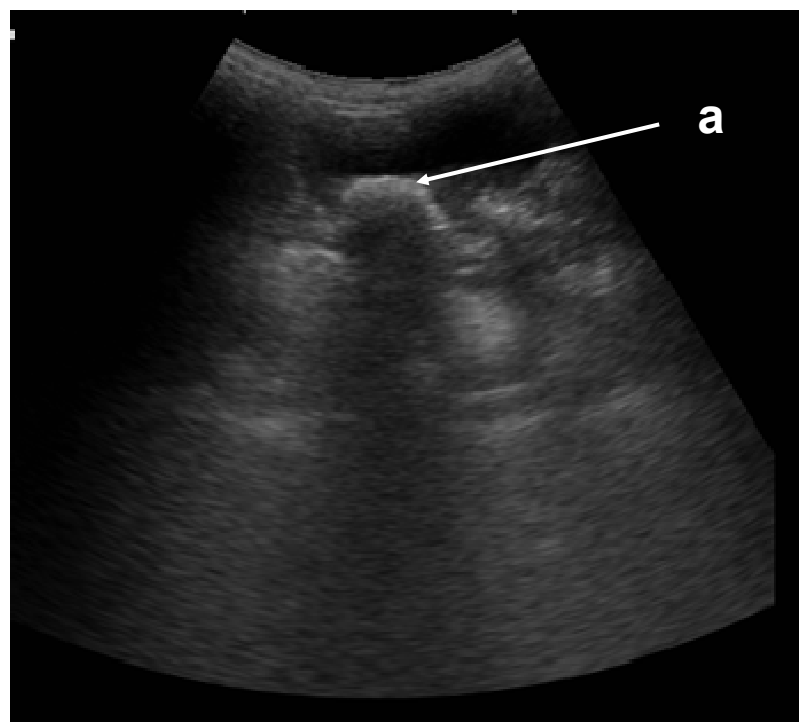

Рис. 1. Ультрасонограма сечового міхура кота за уролітіазу, а-уроліт

Натомість, під час перфузії катетер у сечовому міхурі візуалізувався на моніторі у вигляді тон- кої гіперехогенної лінії, що давало можливість регулювати глибину проникнення. Струмінь розчину наповнював сечовий міхур, спричиняючи відокремлення уролітів від слизової оболонки та їх переміщення, що дало змогу провести дослідження у динаміці та візуалізувати дрібні конкременти.

Завдяки цьому у даної тварини ми виявили уроліт розмірами $4,2 \times 8$ мм, а також три уроліти розміром близько 1,5 мм (рис. 2), тоді як раніше вони залишалися непомітними (рис. 1).

Після проведення ультрасонографії відтягували поршень шприца, видаляючи 3 порожнини сечового міхура введений розчин (разом із сечею та дрібними піщинками), розміри яких не перевищували діаметра катетера (0,6 мм).

Таким чином, ультрасонографія є високоінформативним методом діагностики сечокам'яної хвороби у свійських котів, що дає змогу виявити уроліти й встановити їх кількість та розміри.

Застосування прийому перфузії сечового міхура розширює можливості ультразвукового дослідження у складних випадках (адгезія каменів до слизової оболонки, порожній сечовий міхур), що сприяє підвищенню ефективності діагностики уролітіазу.

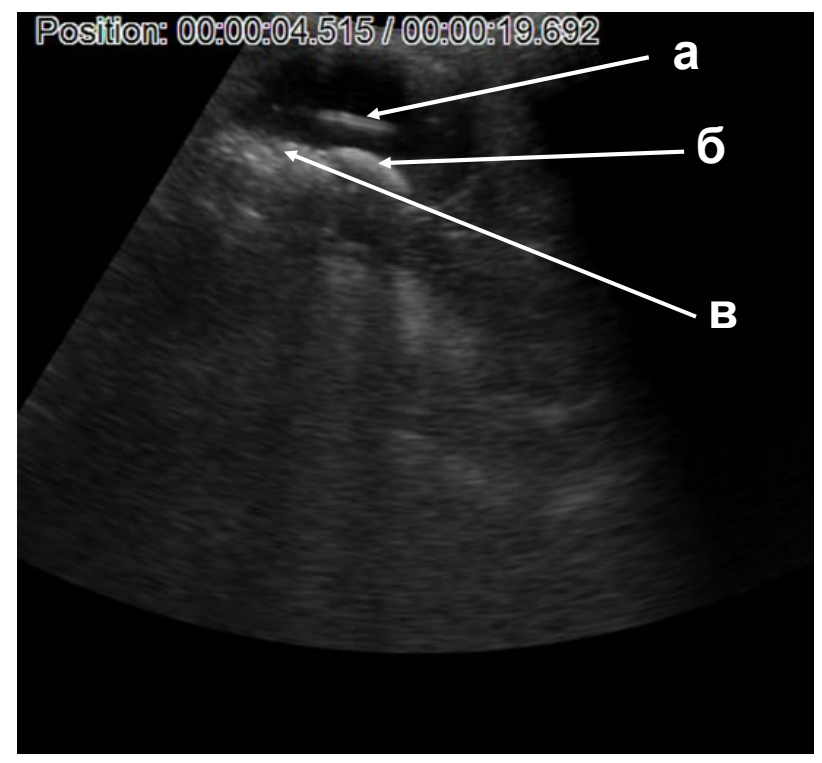

Рис. 2. Ультрасонограма сечового міхура кота за уролітіазу: а-катетер; б, в-уроліти

Висновок. Застосування перфузії під час ультрасонографічного дослідження сечового міхура підвищує інформативність даного методу в діагностиці сечокам'яної хвороби свійських котів. 


\section{БІБЛІОГРАФІЯ}

1. Барр Ф. Ультразвуковая диагностика собак и кошек / Ф. Барр - М. : Аквариум - ЛТД. - 1999. $-250 \mathrm{c}$.

2. Болезни собак и кошек. Комплексная диагностика и терапия болезней собак и кошек: учеб. пособие / [Т. К. Донская, Г. Г. Щербаков, Г. В. Полушин]; под ред. С. В. Старченкова. - С.-Пб. : Спец. лит-ра, 2006. -655 с.

3. Иванов В. В. Клиническое ультразвуковое исследование органов брюшной и грудной полости у собак и кошек / В. В. Иванов - М. : Аквариумпринт, 2005. - $176 \mathrm{c}$.

4. Кондрахін I. П. Уролітіаз у собак і котів / I. П. Кондрахін, П. І. Локес // Вісник Полтав. держ. аграрн. акад. - 2010. - № 2. - С. 93-97.

5. Локес П. І. Сечокам'яна хвороба у собак і кішок / П. І. Локес. - Полтава, 2006. - 80 с.

6. Локес П. І. Ультразвукова діагностика хвороб дрібних тварин / П. І. Локес, В. Г. Стовба, Л. П. Каришева. - Полтава : ФОП Говоров С. В.,
2007. - $128 \mathrm{c}$.

7. Симпсон Дж. В. Клиническое питание собак и кошек. Руководство для ветеринарного врача / Дж. В. Симпсон, Р. С. Андерсон, П. Дж. Маркуелл; пер. с англ. Е. Махиянова. - М. : Аквариум ЛТД, 2001. $-256 \mathrm{c}$.

8. Тилли Л. Ветеринария. Болезни собак и кошек / Л. Тилли, Ф. Смит ; пер. с англ. - М. : ГЭОТАР-МЕД, 2001. - $784 \mathrm{c.}$

9. Чандлер Е. А. Болезни кошек / Е. А. Чандлер, К. Дж. Гаскелл, Р. М. Гаскел : пер. с англ. - М. : Аквариум, $2002-696$ с.

10. Ющенко Г. О. Сечокам'яна хвороба домашніх кішок (патогенез, діагностика, лікування) : автореф. дис. ... канд. вет. наук : спец. 16.00.01 «Діагностика і терапія тварин» / Г. О. Ющенко. Біла Церква, 2005. - 20c.

11. Osborn C. A. Feline lower urinary tract diseases / C. A. Osborn - Philadelphia, 2000. - 1719 p. 